\title{
A Psephological Analysis of the US Presidential Election from Britain Robert Worcester
}

Tags: survey practice

\section{Survey Practice}

Vol. 1, Issue 5, 2008

A Psephological Analysis of the US Presidential Election from Britain

America has elected a black, liberal intellectual. The British psephological tool, "swing," can be used to illuminate the what and the who of the 2008 American Presidential Election. "Swing" measures the votes state-by-state (Table 1) which compares the Bush-Kerry election of 2004 to McCain-Obama in 2008 and the demographic and attitudinal outcome (Table 2) in 2008 compared to 2004 (using exit poll data). In sum, swing measures the number of voters who have 'swung' from one candidate to another between two outcomes. 


\begin{tabular}{|c|c|c|c|c|c|c|c|c|c|}
\hline \multirow[t]{3}{*}{ State } & \multicolumn{4}{|c|}{$\begin{array}{l}2004 \text { USA Presidential } \\
\text { Election Result }\end{array}$} & \multicolumn{4}{|c|}{$\begin{array}{l}2008 \text { USA Presidential Election } \\
\text { Result }\end{array}$} & \multirow[b]{2}{*}{$\begin{array}{l}\text { Obama } \\
\text { Swing }\end{array}$} \\
\hline & Bush & Kerry & Other & $\begin{array}{l}\text { Kerry } \\
\text { Lead }\end{array}$ & McCain & Obama & Other & $\begin{array}{c}\text { Obama } \\
\text { Lead }\end{array}$ & \\
\hline & $\%$ & $\%$ & $\%$ & $\%$ & $\%$ & $\%$ & $\%$ & $\%$ & $\%$ \\
\hline Alabama & 63 & 37 & 0 & -26 & 61 & 39 & 0 & -22 & 2.0 \\
\hline Alaska & 61 & 36 & 3 & -25 & 60 & 38 & 2 & -22 & 1.5 \\
\hline Arizona & 55 & 44 & 1 & -11 & 54 & 45 & 1 & -9 & 1.0 \\
\hline Arkansas & 54 & 45 & 1 & -9 & 59 & 39 & 2 & -20 & -5.5 \\
\hline California & 44 & 54 & 2 & 10 & 37 & 61 & 2 & 24 & 7.0 \\
\hline Colorado & 52 & 47 & 1 & -5 & 45 & 54 & 1 & 9 & 7.0 \\
\hline Connecticut & 44 & 54 & 2 & 10 & 38 & 61 & 1 & 23 & 6.5 \\
\hline Delaware & 46 & 53 & 1 & 7 & 37 & 62 & 1 & 25 & 9.0 \\
\hline Florida & 52 & 47 & 1 & -5 & 49 & 51 & 0 & 2 & 3.5 \\
\hline Georgia & 58 & 41 & 1 & -17 & 52 & 47 & 1 & -5 & 6.0 \\
\hline Hawaii & 45 & 54 & 1 & 9 & 27 & 72 & 1 & 45 & 18.0 \\
\hline Idaho & 68 & 30 & 2 & -38 & 61 & 36 & 3 & -25 & 6.5 \\
\hline Illinois & 45 & 55 & 0 & 10 & 37 & 62 & 1 & 25 & 7.5 \\
\hline Indiana & 60 & 39 & 1 & -21 & 49 & 50 & 1 & 1 & 11.0 \\
\hline Iowa & 50 & 49 & 1 & -1 & 45 & 54 & 1 & 9 & 5.0 \\
\hline Kansas & 62 & 37 & 1 & -25 & 57 & 41 & 2 & -16 & 4.5 \\
\hline Kentucky & 60 & 40 & 0 & -20 & 58 & 41 & 1 & -17 & 1.5 \\
\hline Louisiana & 57 & 42 & 1 & -15 & 59 & 40 & 1 & -19 & -2.0 \\
\hline Maine & 45 & 54 & 1 & 9 & 41 & 58 & 1 & 17 & 4.0 \\
\hline Maryland & 43 & 56 & 1 & 13 & 37 & 62 & 1 & 25 & 6.0 \\
\hline Massachusetts & 37 & 62 & 1 & 25 & 36 & 62 & 2 & 26 & 0.5 \\
\hline Michigan & 48 & 51 & 1 & 3 & 41 & 57 & 2 & 16 & 6.5 \\
\hline Minnesota & 48 & 51 & 1 & 3 & 44 & 54 & 2 & 10 & 3.5 \\
\hline Mississippi & 60 & 40 & 0 & -20 & 57 & 43 & 0 & -14 & 3.0 \\
\hline Missouri & 53 & 46 & 1 & -7 & 49 & 49 & 2 & 0 & 3.5 \\
\hline Montana & 59 & 39 & 2 & -20 & 50 & 47 & 3 & -3 & 8.5 \\
\hline Nebraska & 66 & 33 & 1 & -33 & 57 & 42 & 1 & -15 & 9.0 \\
\hline Nevada & 51 & 48 & 1 & -3 & 43 & 55 & 2 & 12 & 7.5 \\
\hline New Hampshire & 49 & 50 & 1 & 1 & 45 & 54 & 1 & 9 & 4.0 \\
\hline New Jersey & 46 & 53 & 1 & 7 & 42 & 57 & 1 & 15 & 4.0 \\
\hline New Mexico & 50 & 49 & 1 & -1 & 42 & 57 & 1 & 15 & 8.0 \\
\hline New York & 40 & 58 & 2 & 18 & 37 & 62 & 1 & 25 & 3.5 \\
\hline North Carolina & 56 & 44 & 0 & -12 & 49 & 50 & 1 & 1 & 6.5 \\
\hline North Dakota & 63 & 36 & 1 & -27 & 53 & 45 & 2 & -8 & 9.5 \\
\hline Ohio & 51 & 49 & 0 & -2 & 47 & 51 & 2 & 4 & 3.0 \\
\hline Oklahoma & 66 & 34 & 0 & -32 & 66 & 34 & 0 & -32 & 0.0 \\
\hline Oregon & 47 & 51 & 2 & 4 & 41 & 57 & 2 & 16 & 6.0 \\
\hline Pennsylvania & 48 & 51 & 1 & 3 & 44 & 55 & 1 & 11 & 4.0 \\
\hline Rhode Island & 39 & 59 & 2 & 20 & 35 & 63 & 2 & 28 & 4.0 \\
\hline South Carolina & 58 & 41 & 1 & -17 & 54 & 45 & 1 & -9 & 4.0 \\
\hline South Dakota & 60 & 38 & 2 & -22 & 53 & 45 & 2 & -8 & 7.0 \\
\hline Tennessee & 57 & 43 & 0 & -14 & 57 & 42 & 1 & -15 & -0.5 \\
\hline Texas & 61 & 38 & 1 & -23 & 55 & 44 & 1 & -11 & 6.0 \\
\hline Utah & 72 & 26 & 2 & -46 & 63 & 34 & 3 & -29 & 8.5 \\
\hline Vermont & 39 & 59 & 2 & 20 & 31 & 68 & 1 & 37 & 8.52 \\
\hline Virginia & 54 & 46 & 0 & -8 & 47 & 53 & 0 & 6 & $7.0^{2}$ \\
\hline Washington & 46 & 53 & 1 & 7 & 41 & 58 & 1 & 17 & 5.0 \\
\hline
\end{tabular}


Table 1 State-By-State Swing Analysis. 


\begin{tabular}{|c|c|c|c|c|c|c|c|c|c|c|c|}
\hline \multirow[t]{3}{*}{ Demographics } & \multicolumn{5}{|c|}{$\begin{array}{c}2004 \text { USA Presidential Election } \\
\text { Result }\end{array}$} & \multicolumn{5}{|c|}{2008 USA Presidential Election Result } & \multirow[b]{2}{*}{$\begin{array}{l}\text { Obama } \\
\text { Swing }\end{array}$} \\
\hline & Voters & Bush & Kerry & Other & $\begin{array}{c}\text { Kerry } \\
\text { Lead }\end{array}$ & Voters & McCain & Obama & Other & $\begin{array}{c}\text { Obama } \\
\text { Lead }\end{array}$ & \\
\hline & $\%$ & $\%$ & $\%$ & $\%$ & $\%$ & $\%$ & $\%$ & $\%$ & $\%$ & $\%$ & $\%$ \\
\hline \multicolumn{11}{|l|}{ Sex } & 5.0 \\
\hline Men & 46 & 55 & 44 & 1 & -11 & 47 & 48 & 49 & 3 & 1 & 6.0 \\
\hline Women & 54 & 48 & 51 & 1 & 3 & 53 & 43 & 56 & 1 & 13 & 5.0 \\
\hline \multicolumn{12}{|l|}{ Age } \\
\hline $18-29$ & 17 & 45 & 54 & 1 & 9 & 18 & 32 & 66 & 2 & 34 & 12.5 \\
\hline $30-44$ & 29 & 53 & 46 & 1 & -7 & 29 & 46 & 52 & 2 & 6 & 6.5 \\
\hline $45-64$ & 30 & 51 & 48 & 1 & -3 & 37 & 49 & 50 & 1 & 1 & 2.0 \\
\hline $65+$ & 24 & 54 & 46 & 0 & -8 & 16 & 53 & 45 & 2 & -8 & 0.0 \\
\hline \multicolumn{12}{|l|}{ Race } \\
\hline White & 77 & 58 & 41 & 1 & -17 & 74 & 55 & 43 & 2 & -12 & 2.5 \\
\hline $\begin{array}{l}\text { African - } \\
\text { American }\end{array}$ & 11 & 11 & 88 & 1 & 77 & 13 & 4 & 95 & 1 & 91 & 7.0 \\
\hline Latino & 8 & 44 & 53 & 3 & 9 & 9 & 31 & 67 & 2 & 36 & 13.5 \\
\hline Asian & 2 & 44 & 56 & 0 & 12 & 2 & 35 & 62 & 3 & 27 & 7.5 \\
\hline Other & 2 & 40 & 54 & 6 & 14 & 3 & 31 & 66 & 3 & 35 & 10.5 \\
\hline \multicolumn{12}{|l|}{ Income } \\
\hline Under $\$ 15,000$ & 8 & 36 & 63 & 1 & 27 & 6 & 25 & 73 & 2 & 48 & 10.5 \\
\hline$\$ 15-30,000$ & 15 & 42 & 57 & 1 & 15 & 12 & 37 & 60 & 3 & 23 & 4.0 \\
\hline$\$ 30-50,000$ & 22 & 49 & 50 & 1 & 1 & 19 & 43 & 55 & 2 & 12 & 5.5 \\
\hline$\$ 50-75,000$ & 23 & 56 & 43 & 1 & -13 & 21 & 49 & 48 & 3 & -1 & 6.0 \\
\hline$\$ 75-100,000$ & 14 & 55 & 45 & 0 & -10 & 15 & 48 & 51 & 1 & 3 & 6.5 \\
\hline$\$ 100-150,000$ & 11 & 57 & 42 & 1 & -15 & 14 & 51 & 48 & 1 & -3 & 6.0 \\
\hline$\$ 150-200,000$ & 4 & 58 & 42 & 0 & -16 & 6 & 50 & 48 & 2 & -2 & 7.0 \\
\hline$\$ 200,000$ or More & 3 & 63 & 35 & 2 & -28 & 6 & 46 & 52 & 2 & 6 & 17.0 \\
\hline \multicolumn{12}{|l|}{ Education } \\
\hline No High School & 4 & 49 & 50 & 1 & 1 & 4 & 35 & 63 & 2 & 28 & 13.5 \\
\hline H.S. Graduate & 22 & 52 & 47 & 1 & -5 & 20 & 46 & 52 & 2 & 6 & 5.5 \\
\hline Some College & 32 & 54 & 46 & 0 & -8 & 31 & 47 & 51 & 2 & 4 & 6.0 \\
\hline College Graduate & 26 & 52 & 46 & 2 & -6 & 28 & 48 & 50 & 2 & 2 & 4.0 \\
\hline Postgraduate & 16 & 44 & 55 & 1 & 11 & 17 & 40 & 58 & 2 & 18 & 3.5 \\
\hline Democrat & 37 & 11 & 89 & 0 & 78 & 39 & 10 & 89 & 1 & 79 & 0.5 \\
\hline \multicolumn{12}{|l|}{ Party ID } \\
\hline Republican & 37 & 93 & 6 & 1 & -87 & 32 & 90 & 9 & 1 & -81 & 3.0 \\
\hline Independent & 26 & 48 & 49 & 3 & 1 & 29 & 44 & 52 & 4 & 8 & 3.5 \\
\hline Liberal & 21 & 13 & 85 & 2 & 72 & 22 & 10 & 89 & 1 & 79 & 3.5 \\
\hline \multicolumn{12}{|l|}{ Ideology } \\
\hline Moderate & 45 & 45 & 54 & 1 & 9 & 44 & 39 & 60 & 1 & 21 & 6.0 \\
\hline Conservative & 34 & 84 & 15 & 1 & -69 & 34 & 78 & 20 & 2 & -58 & 5.5 \\
\hline \multicolumn{12}{|l|}{ First time voter } \\
\hline Yes & 11 & 46 & 53 & 1 & 7 & 11 & 30 & 69 & 1 & 39 & 16.0 \\
\hline No & 89 & 51 & 48 & 1 & -3 & 89 & 48 & 50 & 2 & 2 & 2.5 \\
\hline \multicolumn{12}{|c|}{$\begin{array}{l}\text { When did you decide } \\
\text { who to vote for }\end{array}$} \\
\hline Today & 5 & 45 & 52 & 3 & 7 & 4 & 45 & 50 & 5 & 5 & -1.0 \\
\hline Last Three Days & 4 & 42 & 55 & 3 & 13 & 3 & 52 & 47 & 1 & -5 & -9.0 \\
\hline Last Week & 2 & 51 & 48 & 1 & $r \overline{-} \stackrel{3}{\text { Prac }}$ & 3 & 50 & 48 & 2 & -2 & $0.5_{4}$ \\
\hline In October & N/A & N/A & N/A & N/A & & 15 & 43 & 54 & 3 & 11 & \\
\hline In September & N/A & N/A & N/A & N/A & & 14 & 45 & 54 & 1 & 9 & \\
\hline
\end{tabular}


The formula is simple: if $a=2008$ result and $b=2004$ result, swing is $(b+a) / 2$, e.g., in 2008 Senator McCain lost to Senator Obama by 46\% to 53\%, a 7 point difference. In 2004, President Bush beat Senator Kerry by $51 \%$ to $48 \%$, a 3 point difference; $(7+3) / 2=5$, in the aggregate, 5 people in 100 switched in 2008 from the Republican candidate to the Democrat.

\section{WHAT TABLE 1 (SWING BY STATE) TELLS US}

Across the USA's 50 states (plus the District of Columbia), totals added up to $127,142,278$ votes. There were 67,066,915 (52.7\%) for Senator Barack Obama; $58,421,377$ (45.9\%) for Senator John McCain, and 1,653,986 (1.3\%) for other candidates. This gave the election to President-elect Obama by 8,645,538 votes $(6.8 \%)$. This equates to a "swing" of $5 \%$, five voters moving from the Republican candidate, George W. Bush, in 2004, to the Democrat, Barack Obama, in 2008.

The state-by-state vote gives us the best data to compare outcome with hypotheses for any number of measures; those who know each state's record and composition, attitudes and values will be able to use these findings to draw their own, and undoubtedly more sophisticated conclusions, but several stand out.

1. The biggest swing in any state was $18 \%$, in Hawaii. There will be several reasons for this. The 'local boy' factor, voters proud to help elect someone born in their state, was one. There were other factors at work, as politics generally and psephology specifically are complex analysis tasks.

Obama attracted racial minorities in larger numbers than ever before. In many speeches and radio and TV interviews, I supported the idea of a slight Bradley effect (no more than $2 \%$ overall) because of the "Reverse Bradley effect" which seems to have impacted Hawaii and other states where a large racial minority exists. Also, where a true Bradley effect does exist, it is largely in already safe Republican ('red') states, mainly in the South.

2. The regional pattern sustains this hypothesis. In the Southern states the swing was less than half (2.3\%) of the national average (5.0\%). Voters in the Southwest were the next least 'enthusiastic' in their support for Obama $(3.5 \%$ swing). The greatest swing to Obama was in the mountain states (7.4). Most others were close to the average, the mostly 'blue' (Democratic) states having a $4.5 \%$ swing, the central states $5.4 \%$, although Indiana, a central state, had, next to Hawaii, the greatest swing. The $11 \%$ magnitude of the swing in Indiana moved Indiana into the Democratic column for the first time since 1964 when the Lyndon Johnson landslide included Indiana. 
3. There were only three states which "counter-swung" to McCain Tennessee $(-0.5 \%)$, Louisiana $(-2.0 \%)$ and Arkansas (-5.5\%). Arkansas may be a combination of disappointment that Hilary Clinton did not win the nomination and a Southern state tradition. The other 47 states all swung to Obama.

4. I have always carried a 'compressed spring' hypothesis that it is easier to move politically from $50 \%$ to $60 \%$ than from $85 \%$ to $90 \%$. This seemed at first inspection to be sustained by the normally strongest Democratic states having low (further) swings to Obama, such as Massachusetts (0.5\%) and District of Columbia (2.5\%), but a quick statistical analysis found otherwise.

5. After removing the explicable states of Hawaii, Arkansas and the District of Columbia, the ten most Democratic states had an average swing of $5.4 \%$, the next ten $5.2 \%$, the third ten $5.2 \%$, the fourth $3.9 \%$ (which contained Indiana), and the last 5.2\%, again. Repeating the exercise by ranking by Republican strength the analysis proved to vary the national $5.0 \%$ by as little a spread as between $4.8 \%$ and $5.2 \%$ across the five segments.

\section{SO WHAT THEN OF TABLE 2 - THE DEMOGRAPHIC AND ATTITUDINAL ANALYSIS?}

6. There was little difference in the gender swing. While in 2004 the $3 \%$ Bush victory turned into a 7\% Obama win in 2008 overall, a "shift" of $10 \%$, among men Bush led by 11 percentage points, $55 \%$ to $44 \%$, while women voted for Kerry $51 \%$ to $48 \%$, a $14 \%$ total, thus a $7 \%$ gender swing.

In 2008, Obama won both among men and women, but men only by $1 \%$ and women by $13 \%$ (which must give the Palin apologists pause for thought). Yet when turned into swing between 2004 and 2008, there was little difference, men $6 \%$ and women $5 \%$. Very little discernable Palin effect.

7. Not so with the age analysis. As predicted, without the 18-29 age cohort (18\% of voters this time vs. $17 \%$ in 2004$)$ and the young's enthusiasm for Obama, the election would have been much closer. The 18-29s swung 12.5\% to Obama between 2004 and 2008, with no fewer that two thirds, $66 \%$, voting for Obama vs. $32 \%$ who voted for $\mathrm{McC}$ ain, giving the Democratic candidate a $34 \%$ lead in 2008. This was a huge jump up from just $9 \%$ more of younger people voting Democratic in 2004.

There was also an above average swing among the next older cohort, $30-44,6.5 \%$. The next cohort $(45-64 \mathrm{~s})$ was down to $1 \%$, and a nil swing among the quarter (18\% in $2008,24 \%$ in 2004$)$ of voters in the $65+$ age group, who gave McCain almost exactly the same percentage 
of the vote that they gave Bush four years earlier.

8. Nor race, for if only the $77 \%$ of voters who are white had voted, Senator McCain would be the President-elect. Of the quarter (23\%) of voters who are not, 19 out of 20 blacks voted for Obama and just $4 \%$ for McCain. Among Latinos, two-thirds voted for Obama.

Much was made of the voting patterns of Hispanics/Latinos by the media early on. The received wisdom was that they would not vote for a black man in great numbers. In 2004 this was true to some extent, but only to the extent that they were less supportive of Kerry (53\%) than were blacks (88\%).

Still, Latinos gave Kerry a 9\% lead then, but a massive 36\% in 2008 . Their $13.5 \%$ swing to Obama was among the biggest of any grouping. They now represent $9 \%$ of all voters. Asian-Americans are still but $2 \%$ of the electorate, and they too swung to Obama, by $7.5 \%$, half again the $5 \%$ average across all groups.

9. One of the biggest swings came from a tiny but important segment of the electorate. Just three percent of the electorate in 2004 admitted to the exit poll interviewers that their household income exceeded $\$ 200,000$, and then they voted by $63 \%$ to $35 \%$, nearly by two to one, for President Bush over Senator Kerry.

Despite the Obama promise that he would introduce tax cuts for $85 \%$ of the American taxpayers (and that clearly meant a tax rise for the wealthy), they nonetheless swung by a massive $17 \%$ to give Obama a $52 \%$ to $46 \%$ win in their household income segment (in 2008 , their ranks had increased by $100 \%$, from the $3 \%$ they amounted to in 2004 to $6 \%$ in 2008). This finding destroys the media's false premise that people tell pollsters they will vote Labour/Democrat, but if threatened by tax rises they don't in the voting booth. It was clearly not the case in Britain in the 1997 Blair landslide or in USA in 2008 .

10. The other important income group for Obama was the least well off, which includes a disproportionate percentage of black voters, who have household incomes of under $\$ 15,000$, and who gave Obama a $10.5 \%$ swing. Only among the next income cohort, the $\$ 15,000$ to $\$ 30,000$ income group, was a below 5.0\% swing measured, $4.0 \%$.

11. Those $4 \%$ who are the least well schooled, with no high school, again disproportionately black, were strong supporters of Obama, giving the Democrat a $13.5 \%$ swing and a majority of $28 \%$ this time, compared with just $1 \%$ in 2004 . Counter-intuitively, those with a college education, even those with post-graduate education, swung somewhat less to Obama than the average.

Since the days of Adali Stevenson there has been the hypothesis that less-well educated voters wouldn't vote for an intellectual. Those with 
no high school with their $13.5 \%$ swing, against the less than $4 \%$ for those with at least one college degree, showed that other things trumped anti-intellectualism.

12. Party ID is an important factor in American elections. According to the always useful Pew polling, towards the end of the long campaign $37 \%$ said they thought of themselves as Democrats while 31\% were Republican supporters. In the popular vote, it is much easier to get to $50 \%+1$ from $37 \%$ than $31 \%$. That said, the nine in ten of Democrats told the Edison Media Research interviewers that they'd voted for Obama, and nine in ten Republicans supported McCain.

Before the election began, the Democrats had a record ten point lead in party ID. The $28 \%$ of those who wear the 'I vote for the person, not the party' badge, the independents (unknown in British political parlance) were running practically even in 2004, with just a one point lead for Kerry; this time it was a $3.5 \%$ swing to Obama, $52 \%$ to $44 \%$. Obama did well with them, but not nearly as well as the pundits and analysts had anticipated. They represented $26 \%$ of voters in $2004,29 \%$ in 2008.

13. America voted for a self-confessed 'liberal.' It wasn't long ago that 'liberal' was a dirty word in American folklore; anyone who was tarred with the 'liberal' brush could not be elected. Obama, a self-confessed liberal just was. The ideology profile of the 2004 American voter was $21 \%$ liberal, $45 \%$ moderate, and $26 \%$ conservative. In 2008 it was $22 \% / 44 \% / 34 \%$, not much different.

In $2004,85 \%$ of liberals voted for Kerry, in 2008, $89 \%$ for Obama. There the 'compressed spring' theory works, for Obama's swing was 3.5\%. Among moderates, who split more evenly last time than this, the swing was $5.5 \%$. Even among Conservatives there was an above average swing of $6.0 \%$.

14. First-time voters in 2004 gave Kerry a 7 point lead; in 2008 , they voted $69 \%$ to $30 \%$, delivering a massive 16 point swing to Obama. They were $11 \%$ of voters in both 2004 and 2008. Another myth turned over.

15. One of the most intriguing findings from the exit poll this year is that while in 2004 those wavering voters who decided finally how they were going to vote in the last three days of the campaign gave a 13 point lead to Kerry, in 2008, they leaned to McCain, giving him a five point lead, $52 \%$ to $47 \%$.

16. Protestants ( $54 \%$ of voters both then and now) swung to Obama by an average $5.0 \%$, Catholics (27\%) $7.0 \%$, and Jewish (2\%) by $4 \%$. The respective leads were McCain by $9 \%$, Obama by $9 \%$ and among Jews a massive $78 \%$ to $21 \%$, nearly four to one. 
17. McCain's choice of Sarah Palin as his vice presidential running mate probably captured more headlines than any other single event in the election, and certainly more discussion. There are no comparative figures from 2004, but the result is certainly interesting if a bit contradictory.

There are two pair of findings: of the $7 \%$ of voters who considered Palin's appointment as the most important issue of the election to them, there was a five point Obama lead and of the rest who said it was important (not 'most' important), a third of voters, it was a five point lead to McCain. On the 'minor factor' group, one in five, a massive 2:1 lead for Obama, but an equally huge 2:1 lead for McCain among those who said it was not a factor, and they were a third of voters.

18. One most interesting finding relates to the $12 \%$ of the voters who are members of trade unions, especially because it had been reported that Barack Obama has given the unions a promise both to abolish the Right to Work Act and the secret ballot for officers of trade unions. Did they reward him? Not on your nelly. There was a nil swing from Kerry among union members, while those who do not belong to trade unions swung half again beyond the average, to $7.5 \%$. 